\title{
Geografija in celostni razvoj podeželja
}

\author{
Stanko Pelc \\ Dr., Pedagoška fakulteta, Univerza v Ljubljani, Kardeljeva ploščad 16, \\ 1000 Ljubljana, Slovenija \\ e-mail: stanko.pelc@uni-lj.si
}

\section{Izvleček}

Obravnavan je položaj geografije podeželja v slovenski geografiji. Uporabljeni so bili nekateri podatki o pojavljanju geografije podeželja $v$ različnih študijskih programih in bibliografski podatki o obsegu gradiva s tega področja v osrednji geografski knjižnici. Podan je pregled geografskih del, ki bi jih lahko uvrstili v okvir aplikativne geografije podeželja in opredeljene njene možnosti za uporabo v projektih celostnega razvoja podeželja v Sloveniji.

Ključne besede: geografija podeželja, razvoj podeželja

\section{Geography and Sustainable Development of the Countryside}

\begin{abstract}
We write about the position of rural geography within Slovene geography and its possible application in the process of integrated rural development. We draw our conclusions on the basis of the presence of rural geography as a course in study programmes in Slovenian and some foreign Universities, the amount of bibliographical units from the field of rural geography in the central geographical library of Slovenia and our experiences with the project of integrated rural development and the village renovation in Slovenia.
\end{abstract}

Key words: rural geography, rural development 


\section{UVOD}

V Sloveniji podeželska območja obsegajo večino območja države. Ker velikih mest Slovenija nima, je njen podeželski značaj še toliko bolj izstopajoč. Slovensko podeželje je zelo raznoliko. Poleg naravno-geografskih dejavnikov je za to $\mathrm{v}$ veliki meri kriva, predvsem $\mathrm{v}$ zadnjih desetletjih hitro napredujoča in obsežna, preobrazba. Danes podeželsko prebivalstvo, z dobro dostopnostjo do središčnih naselij višjih stopenj, uživa prednosti življenja $v$ prijetnejšem in običajno bolj zdravem okolju, pri čemer se mu ni treba odrekati prednostim, ki jih nudi pestra izbira tako na področju oskrbe kot delovnih mest in poslovnih priložnosti v mestih. Drugače je seveda na območjih s slabšo dostopnostjo. Tam je povprečna življenjska raven precej nižja, drugačen je tudi način življenja in gospodarjenja tamkajšnjega prebivalstva. Večja je odvisnost od kmetijstva in gozdarstva. Ker gre $\mathrm{v}$ takih primerih navadno tudi za območja $\mathrm{z}$ manj ugodnimi pogoji za kmetovanje, je gospodarska uspešnost temu primerno slabša. Na takih območjih se srečujemo s številnimi razvojnimi problemi. Nizka življenjska raven, manjša gostota prebivalstva, odseljevanje mladega prebivalstva, neugodna starostna, spolna in izobrazbena sestava prebivalstva pa pomembno vplivajo na nastajanje in kopičenje različnih socialnih in prostorsko-ureditvenih problemov.

Slovenski geografi so se predvsem od šestdesetih let prejšnjega stoletja naprej veliko ukvarjali s preobrazbo podeželja, ki je ravno takrat začela dobivati vse večji obseg, hkrati pa je njihovo raziskovalno pozornost pritegnil tudi nerazviti in razvojno zaostajajoči del podeželja. V nekaj desetletjih so bile opravljene številne raziskave, ki so obogatile zakladnico znanja o slovenskem podeželju in procesih, ki usmerjajo njegov razvoj. O tem, kakšno mesto je to znanje dobilo pri načrtovanju sprememb na podeželju in pri odpravljanju razvojnih in drugih problemov, je znanega bolj malo. V tem prispevku je navedena vrsta avtorjev, ki so v povojnem obdobju utemeljili geografijo podeželja in vzgajali strokovnjake, ki se $\mathrm{v}$ zadnjih desetletjih vse bolj podajajo tudi na področje uporabe raziskovalnih dognanj v praksi.

Številni slovenski geografi, ki delajo na zelo raznolikih področjih, s pridom uporabljajo teoretična spoznanja naše vede pri svojem vsakdanjem delu. Zaradi razmeroma dobrega poznavanja številnih raznorodnih pojavov in procesov ter zapletenosti in prepletenosti povezav med njimi so mnogi med njimi tudi cenjeni in iskani strokovnjaki na področju urejanja prostora in regionalnega razvoja. V zadnjih letih se vse bolj uveljavljajo tudi na področju celostnega razvoja podeželja. Prav na tem področju bi bila lahko vloga geografije večja kot trenutno je. Namen tega prispevka je podati nekaj značilnosti geografije podeželja in opredeliti njen položaj v okviru slovenske geografije. Ker 
je razvoj podeželskih območij ključna problematika, kjer se lahko v praksi uveljavijo raziskovalni dosežki geografije podeželja, je namen prispevka tudi, prikazati trenutno stanje organiziranega pristopa $\mathrm{k}$ celostnemu razvoju podeželja v Sloveniji in opozoriti na možnosti, ki jih ima geografija podeželja za vključitev vanj.

\section{GEOGRAFIJA PODEŽELJA IN NJEN POLOŽAJ V OKVIRU SLOVENSKE GEOGRAFIJE}

D. Kladnik (1999) je v uvodu v Leksikon geografije podeželja zapisal, da je to panoga družbene in regionalne geografije. Taka razvrstitev je nedvomno posledica dejstva, da $v$ sistematiki geografske vede ta panoga še nima nedvoumno opredeljenega mesta in zato vsekakor drži zapisana trditev, da kot znanstvena disciplina še ni docela oblikovana. Zanjo je značilna tematska vezanost na probleme in značilnosti podeželja. V tem smislu je podobna veliko bolj uveljavljeni mestni oziroma urbani geografiji. Njena povezanost $\mathrm{z}$ agrarno geografijo je ponekod, predvsem $v$ gospodarsko manj razvitih deželah, še vedno tesna, vendar je po drugi strani v gospodarsko razvitejšem delu sveta meja med njima vse bolj jasna. Če agrarno geografijo lahko brez sence dvoma uvrstimo v področje ekonomske in s tem družbene geografije pa je mesto geografije podeželja veliko bolj nejasno in razpeto med družbeno in regionalno geografijo. Glavni tematski sklopi, ki sodijo v raziskovalno področje osamosvojene geografije podeželja so depopulacija, širjenje mestnih vplivov in mestnega načina življenja na podeželje, vpliv rekreacije in turizma, strukturne spremembe $\mathrm{v}$ kmetijstvu ter ruralno planiranje (Kladnik o. c.). Prav slednje je najbolj neposredno povezano $\mathrm{z}$ raziskovanjem za praktične potrebe (npr. razvoja podeželja in obnove vasi).

Da je geografija podeželja kot posebna disciplina slabo uveljavljena, potrjuje tudi to, da npr. P. Haggett (1983) v svoji Geografiji namenja mestom in urbanizaciji enega od štirih delov knjige oziroma kar petino vseh poglavij. Podeželju ni posvečeno niti eno. V stvarnem kazalu gesla podeželje ali podeželsko sploh ni, tudi kmetijstvo je obravnavano po obsegu zelo skromno in v več različnih kontekstih. Tudi precej novejša Geografija D. Waugh-a (1995) ne pozna pojma geografija podeželja (rural geography) vendar je avtor podželski problematiki namenil zelo kratko poglavje o rabi zemljišč na podeželju (Rural land use). Precej več pozornosti je posvetil kmetijstvu in oskrbi s hrano. Podeželje je opredelil kot redkeje poseljena območja, kjer v vidnem smislu prevladujejo naravne sestavine pokrajine (countryside elements). Natančnejša omejitev je po njegovem odvisna od tega, kakšne kriterije uporabimo. Ekonomski, se nanašajo na odvisnost prebivalstva od kmetijstva kot poglavitne 
dejavnosti za pridobivanje dohodka, družbeni in prebivalstveni na t. i. podeželski način življenja in na majhno gostoto prebivalstva, prostorski pa na oddaljenost od pomembnejših mestnih središč. Povsem se lahko strinjamo s trditvijo, da jih je običajno zelo težko enovito in jasno opredeliti, saj se pogosto stapljajo z mestnimi območji $\mathrm{v}$ mestno podeželskem obroču okrog mest. Velike razlike med podeželskimi območji so tudi med različnimi območji sveta. Sicer pa je Waughov pristop k obravnavanju podeželja, kot pove že naslov poglavja, podrejen rabi zemljičč in konkurenci med različnimi rabami (kmetijstvo, gozdarstvo, turizem, izkoriščanje naravnih bogastev, oskrba z vodo, promet, poselitev itn.).

V slovenski geografiji posvečamo podeželju nedvomno več pozornosti kot marsikje drugje po svetu. Geografija podeželja je pri nas v okviru študija geografije eden od obveznih predmetov tako na oddelku za geografijo na Univerzi v Ljubljani kot v Mariboru. Naključen vpogled v predmetnike tujih univerz daje slutiti, da so npr. predmetniki v Angliji in ZDA precej bolj problemsko in s tem tudi aplikativno naravnani kot pri nas. Veliko pozornosti namenjajo mestom in razvoju, medtem ko je podeželje obravnavano zgolj posredno. Tako denimo na »Clark University « ni niti sledu o geografiji podeželja, čeprav imajo zelo pester nabor predmetov, med katerimi najdemo celo take kot je geografija Marksovega Kapitala. Geografije podeželja ne najdemo niti na znamenitih angleških univerzah Cambridge in Oxford (na slednjem imajo med izbirnimi predmeti enega, ki se ukvarja z evropskimi kmeti: »European Peasantries«). Tudi pri Nemcih ni dosti drugače! Med številnimi pregledanimi predmetniki, ki si jih je mogoče ogledati na svetovnem spletu, v nobenem nismo našli predmeta, pri katerem bi se dalo iz naslova sklepati, da mu je osrednja tema podeželje. V našem neposrednem sosedstvu na zagrebškem vseučilišču je stanje podobno kot pri nas. V programu oddelka za geografijo je namreč »ruralna geografija«. Pač pa v Avstriji ne v Gradcu ne v Celovcu ni predmeta, ki bi se neposredno ukvarjal s podeželjem, medtem ko na dunajski univerzi v okviru študijskega programa geografije in ekonomije (Geographie und Wirtschaftskunde) lahko zasledimo predmet: geografija podeželskega življenjskega prostora (Geographie des Ländlichen Lebensraumes). V sosednji Italiji lahko v Milanu izberete modul kmetijstvo in podeželje (Agricoltora e mondo rurale). Med nekaj pregledanimi švicarskimi in francoskimi programi za študij geografije sta le v Touluse-u predmeta podeželsko in mestno (Le rural et l'urbain) ter družba in podeželje (Societé et espace ruraux), v Bernu pa imajo v okviru predmeta o naseljih sklop, ki obravnava razvoj naselij na podeželju.

O vlogi geografije podeželja v sklopu geografske vede v Sloveniji se da posredno sklepati tudi po številu bibliografskih enot, ki so $\mathrm{s}$ tega področja na voljo v naši osrednji geografski knjižnici na Oddelku za geografijo filozofske 
fakultete. Smiselna je predvsem primerjava s tematskim sklopom mestne (urbane) geografije. Mesto in podeželje sta namreč, kljub medsebojni povezanosti in dopolnjevanju, dva med seboj izključujoča se »pokrajinska tipa«. Tudi opredelitve podeželja ob pomanjkanju zanesljivih in nedvoumnih kriterijev največkrat temeljijo prav na tem dejstvu. Podeželje je vse kar ni mesto in mesto je to kar ni podeželje. Lahko bi rekli, da je Slovenija z razmeroma nizko stopnjo urbanizacije pretežno podeželska država. Zato je smiselno ugotavljati, kateremu vsebinskemu področju (mestni geografiji ali geografiji podeželja) je bilo v slovenski geografiji posvečene več pozornosti. Zgolj število bibliografskih enot ni najbolj zanesljiv kazalnik za to, vendar bi podrobnejša analiza zahtevala preveč časa. Navedene ugotovitve imajo zato nekoliko manjšo težo, vendar kljub temu nakazujejo določeno razmerje med raziskovalno in študijsko pozornostjo, ki jo imata pri slovenskih geografih mesto in podeželje.

Primerjava med številom zadetkov med gesloma podeželje in mesto ${ }^{1} \mathrm{~s}$ pomočjo sistema Cobiss nam kaže, da so mesta več kot očitno precej bolj obravnavana tema kot podeželje (slika 1).

Na grafikonu so posebej prikazani zadetki za slovenski in angleški jezik, saj je v teh dveh velika večina vsega gradiva (od 71,6\% pri monografskih publikacijah o mestih do $94,3 \%$ pri člankih o podeželju). Razmerje med številom zadetkov je izrazito $\mathrm{v}$ korist tistih $\mathrm{z}$ »mestno-geografsko bibliografsko oznako« in se giblje med približno 1:4 pri slovenskih monografskih publikacijah in približno 1:3 pri člankih ne glede na jezik. Če bi na enak način primerjali poeželje s prometom, bi ugotovili, da je $\mathrm{v}$ geografiji promet precej zanimivejši od podeželja a hkrati pol manj zanimiv kot mesta, medtem ko turizem krepko presega vse tri. Podeželje torej, vsaj kar se objav in obsega literature tiče, tudi v slovenski geografiji ni med vodilnimi področji.

Paleta tem, s katerimi so na področje geografije podeželja v preteklosti posegali slovenski geografi, je dokaj pisana. S planinami in planinskim gospodarjenjem se je ukvarjal že A. Melik in za njim M. Vojvoda, s hribovskimi kmetijami D. Meze, s sistemi poljske razdelitve S. Ilešič, I. Vrišer pa s sistemi agrarnega izkoriščanja tal v Sloveniji. Med vidnejšimi slovenskimi geografi so se v šestdesetih in sedemdesetih letih podeželju bolj ali manj posvečali še B. Belec, L. Gosar, J. Medved in seveda V. Klemenčič, ki je bil dolga leta tudi nosilec predmeta geografija podeželja. Tudi sicer ne gre prezreti njegovega prispevka k usmeritvi raziskovalnega polja slovenske geografije podeželja $\mathrm{k}$

\footnotetext{
${ }^{1}$ Uporabljeni gesli za ključni besedi sta bili: in podežel* in geograf* ter: in mest* in geograf*, ki izbereta vse zapise, v katerih se kot ključni besedi pojavljata katerakoli izpeljanka iz korena geograf in hkrati katerakoli izpeljanka iz korena podežel (npr.: podeželje+geografija naselij, geografija podeželja...) oziroma katerakoli izpeljanka iz korena geograf in hkrati katerakoli izpeljanka iz korena mest (npr.: mestna geografija, geografija naselij+ mesto...).
} 
problematiki preobrazbe in njenim posledicam. Številni geografi, ki so se raziskovalno uveljavili v zadnjih dveh do treh desetletjih je mentorsko popeljal na raziskovalno področje geografije podeželja prav on (doktoranti: L. Gosar, M. M. Klemenčič, T. Kürbus, pa tudi M. Ravbar, saj njegova tema suburbanizacija prav tako obravnava preobrazbo slovenskega podeželja).

Slika 1: Število zadetkov za gesli in mest* in geograf* ter in podežel* in mest* za vse gradivo skupaj ter posebej za članke in monografske publikacije glede na jezik

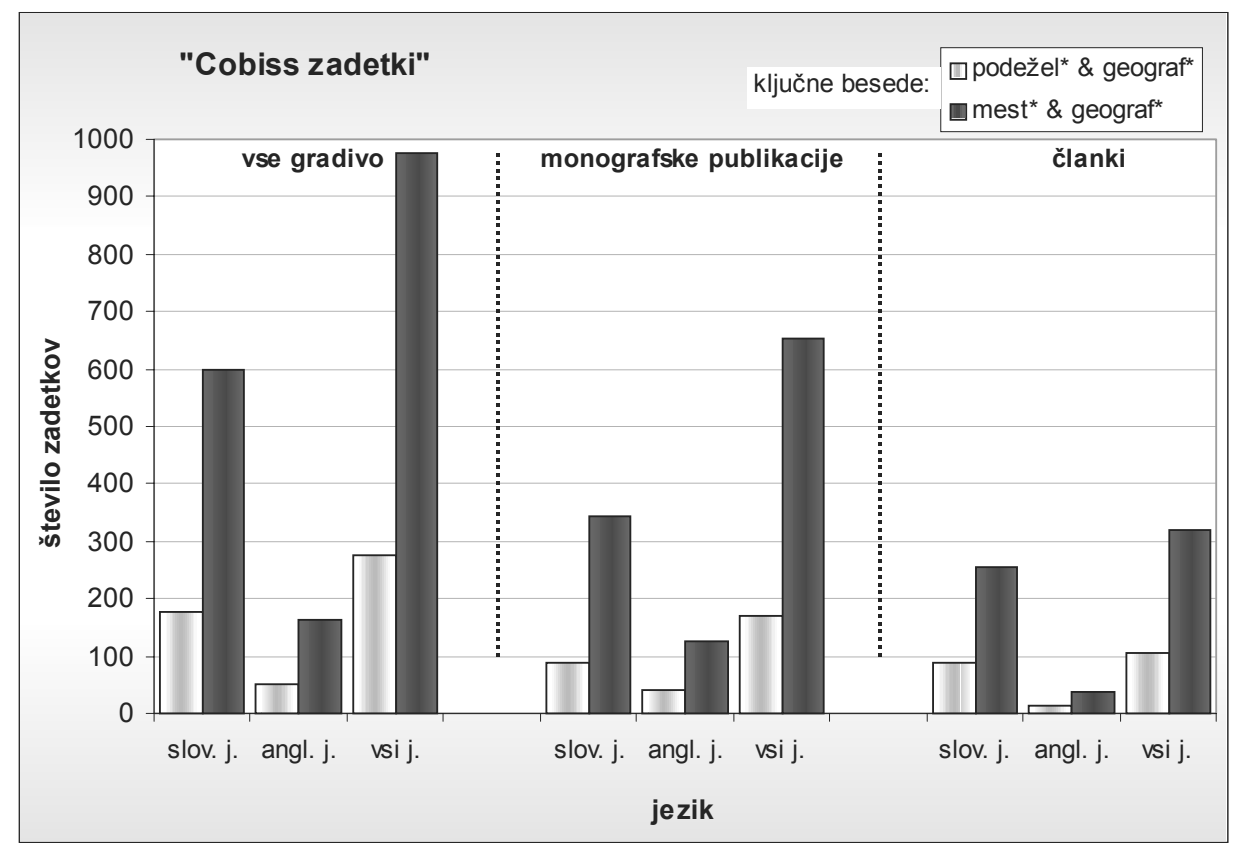

(Vir: Cobiss, kooperativni online bibliografski sistem in servisi, vzajemna bibliografsko-kataložna baza podatkov COBIB.SI: FF, Osrednja humanistična knjižnica, Ljubljana, Oddelek za geografijo)

V zadnjih desetletjih so se slovenski geografi, s svojim širokim znanjem in sposobnostjo povezovanja spoznanj z različnih področij v smiselno celoto, uveljavili na različnih področjih. Poleg tega je stanje v družbi narekovalo tudi vse večjo usmeritev $\mathrm{v}$ uporabno naravnano raziskovanje. Tako imenovani aplikativni pristop lahko do neke mere opazimo tudi v geografiji podeželja. Med bolj opaznimi raziskovalci in avtorji je v tem pogledu najprej treba omeniti M. M. Klemenčiča, ki se je ukvarjal z razvojnimi možnostmi gospodarsko šibkega podeželja, pisal o turizmu na podeželju in hkrati mentorsko usmerjal študente 
pri temah kot so razvojni dejavniki na podeželskih območjih. S planiranjem na podeželju so se precej ukvarjali sodelavci Urbanističnega inštituta, v okviru katerega so bile opravljene raziskave, ki so obravnavale vsebine ruralnih naselij za potrebe usmerjanja njihovega razvoja (P. Mihevc in drugi), podeželje kot razvojno in prostorsko plansko posebnost (P. Miheve), analizo agrarne pokrajine za potrebe urbanističnega načrtovanja (B. Ogorelec). Pod mentorstvom I. Vrišerja je na Oddelku za geografijo z diplomskim delom na to področje posegla M. Požeš (Prostorsko planiranje na podeželju). Med negeografi je treba v tem okviru omeniti Prosena z njegovim delom Planiranje podeželskega prostora.

Predvsem v zadnjem desetletju je geografija podeželja v aplikativnem smislu najbolj prisotna na področju celostnega razvoja podeželja. Poleg avtorja tega prispevka, ki je tudi pisec strokovnih besedil za usmerjanje razvojnih dejavnosti v okviru programov za razvoj podeželja, so na tem področju dejavno zastopani še M. Koščak, L. Gosar (s svojimi praktičnimi izkušnjami in metodološkimi razmišljanji posega tudi na področje regionalnega planiranja na podeželju), sodelavci Geografskega inštituta Antona Melika (s svojimi raziskovalnimi prispevki so že večkrat posegli tudi na povsem praktično področje raziskovanja podeželskih značilnosti za razvojne potrebe; npr. M. Topole, M. Gabrovec). Občasno s svojimi prispevki na to področje poseže tudi V. Drozg (Vinske ceste kot element regionalnega razvoja obmejnih območij). Po svoji naravi bi $\mathrm{v}$ ta sklop sodila tudi diplomska dela kot so npr. delo A. Magajneja (Razvojne možnosti in problemi hribovskega sveta na primeru Masor), J. Marinka (Razvoj in revitalizacija slovenske vasi - metodologija vrednotenja in sprejemanja izhodišč za revitalizacijske posege $v$ ruralnih naseljih) oz. T. Povirkove (Geografski učinki malih industrijskih obratov na podeželje). Posredno posega na to področje tudi I. Potočnikova, ki je v Sodobnem kmetijstvu pisala o geografskem vidiku dopolnilnih dejavnosti na slovenskih kmetijah.

$\mathrm{Na}$ področje razvoja podeželja pa seveda $\mathrm{z}$ aplikacijo svojega raziskovalnega dela posegajo tudi strokovnjaki drugih strok. Med njimi je po obsegu svojega dela, izkušnjah in uveljavljenosti v praksi vsekakor najbolj znan M. Kovačič, ki je sam ali s sodelavci (npr. Perparjem, Sunčičem in drugimi) pisal o razvojnem stanju, značilnostih in problemih podeželskih območij v Sloveniji; socioekonomskih dejavnikih in modelih razvoja kmetijstva in podeželja; pripravi in izvajanju programa celovitega razvoja itn. V zadnjem času je raziskovalno dejaven na področju razvoja podeželja tudi L. Juvančič. Med krajiskimi arhitekti na to področje posega I. Marušič (Priprava programa prostorskega razvoja - razvoja podeželja), med sociologi pa A. Barbičeva. Na koncu je treba omeniti, da je $\mathrm{v}$ podiplomski študijski program na Biotehniški fakulteti vključen tudi predmet razvoj podeželja. 
Glede na zelo aktualno vključevanje Slovenije v Evropsko zvezo, ki bo imelo daljnosežne posledice tudi za slovensko podeželje, je prav da omenimo tudi prispevek D. Kladnika Problematika preobrazbe podeželja z vidika prilagajanja kmetijske pridelave normativom $v$ Evropski zvezi. Ta avtor ima tudi sicer kar obsežen opus s področja geografije podeželja. Do določene mere je aplikativno naravnan tudi njegov prispevek Možnosti intenziviranja rabe kulturnih teras, kar bi lahko rekli tudi za prispevek M. Deklevove Možnosti vključevanja podeželskih naselij koprskega primorja v turistično ponudbo območja.

V zgornji kratek pregled ni bilo mogoče zajeti vseh avtorjev in vseh del, ki bi jih lahko uvrstili v področje vsaj delno aplikativne geografije podeželja. Bolj kot sistematičnost naj bi bila zanj značilna ilustrativnost, ki kaže glavna področja raziskovalnega dela in raznovrstnost raziskovalnih usmeritev različnih avtorjev.

\section{CELOSTNI RAZVOJ PODEŽELJA IN OBNOVA VASI (CRPOV)}

Izvajanje programa celostnega razvoja podeželja in obnove vasi se je začelo $\mathrm{v}$ času osamosvojitve Slovenije, projekt pa vodi, usmerja in financira Ministrstvo za kmetijstvo, gozdarstvo in prehrano (MKGP). Poleg tujih zgledov je na nastanek programa in začetek njegovega izvajanja vplivala tudi nakopičenost raznovrstnih problemov na našem podeželju. To je narekovalo uporabo celostnega pristopa, saj je reševanje samo posameznih problemov neučinkovito (Pelc 2000).

Leta 1991 je bilo v CRPOV kot državni projekt vključenih prvih 17 naključno izbranih lokacij. Temeljni smoter projekta je bil usposobiti prebivalce na območjih, kjer projekt poteka, za izvajanje razvojnih dejavnosti z uporabo projektnega pristopa. Izdelani projekt za posamezno območje naj bi celostno reševal probleme območja, prispeval k aktiviranju ustreznih razvojnih usmeritev in hkrati ohranjal in varoval značilnosti podeželja in vasi na območju.

Projekt je na državni ravni skupek posameznih majhnih, prostorsko omejenih projektov, ki jih na podlagi razpisov financira MKGP. Projekti obsegajo tri faze (Pelc 1999): pripravo-uvajanje-izvajanje. V pripravljalnem delu, se na pobudo prebivalcev območja, ki se želijo vključiti v projekt, opredelijo značilnosti, problemi območja ter ključni interesi prebivalcev. V tej fazi je geografska preučitev območja zelo koristen dejavnik za uspešnost priprav in nadaljevanje dela v naslednji fazi. Do te običajno pride le, če občina za območje pridobi sredstva MKGP, s katerimi sofinancira program uvajanja in izdelave projekta CRPOV. To delo naj bi trajalo eno leto in naj bi ga izvajala za to uspo- 
sobljena izvajalska organizacija $\mathrm{z}$ ustrezno interdisciplinarno sestavljeno strokovno skupino.

Slika 2: Shema uvajanja celostnega razvoja podeželja in obnove vasi (CRPOV)

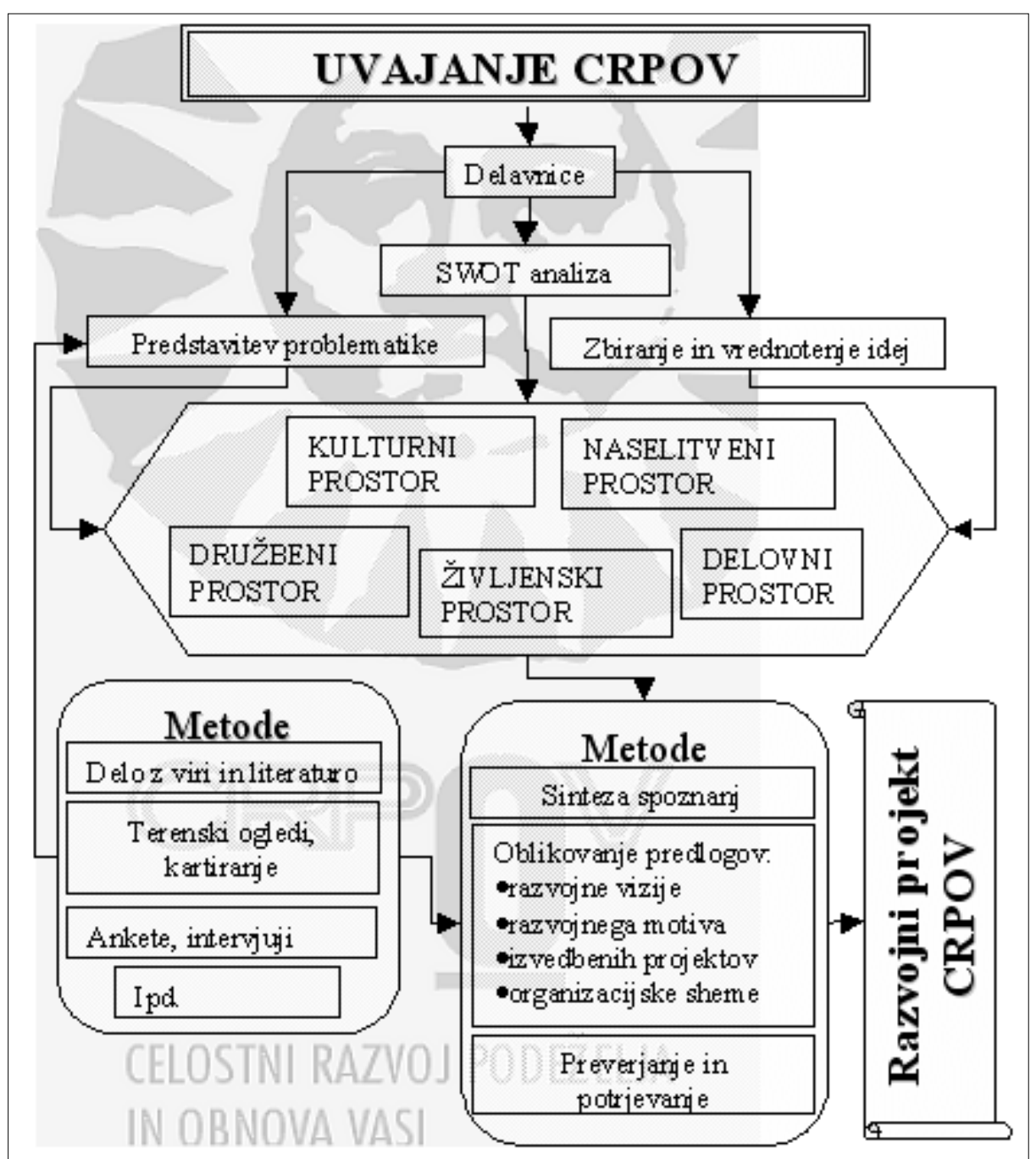

Program uvajanja je izobraževalni program za usposabljanje prebivalcev območja za celostno razvojno razmišljanje in delovanje. V okviru različnih tematskih sklopov ugotavljajo možnosti in priložnosti območja ter ovire in nevarnosti. Na podlagi tega opredelijo razvojne možnosti. Pomembno je po- 
skrbeti za motiviranost prebivalcev za lasten razvoj in za potrebno ustvarjalno vzdušje, v katerem se rojevajo ideje za razvojne projekte, s katerimi je mogoče uresničevati razvojne cilje. Ti morajo izhajati iz razvojne vizije, ki jo ob strokovni pomoči oblikujejo prebivalci območja sami. Na podlagi opravljenih izobraževalnih delavnic s prebivalci (SWOT ${ }^{2}$ analize, ideje, usmeritve), rezultatov vprašalnikov, terenskih ogledov, analize pisnega gradiva in statističnih podatkov o območju itn. izvajalska organizacija pripravi končni razvojni projekt CRPOV. V njem so opredeljeni razvojna vizija, cilji za njeno opredelitev, naloge ter izvedbeni projekti za njihovo uresničitev itn.

Uvajanju sledi izvajanje projekta CRPOV oziroma uresničevanje izvedbenih projektov v skladu z opredeljenimi prioritetami in finančnimi ter organizacijskimi možnostmi posameznih investitorjev. Tudi $\mathrm{v}$ tej fazi lahko bodisi vaška skupnost, občina ali individualni investitorji na vsakoletnih razpisih pridobijo nepovratna sredstva od MKGP in drugih ministrstev ali pa ugodna posojila iz skladov za razvoj (podeželja).

$Z$ vidika povezave med uporabno vlogo geografije podeželja v okviru celostnega razvoja podeželja je za nas zanimiva predvsem faza uvajanja in izdelave razvojnega projekta CRPOV.

\section{UPORABA GEOGRAFIJE V OKVIRU CRPOV}

Za geografijo radi rečemo, da je zelo široka in kompleksna veda, ki je hkrati tudi most med naravoslovjem in družboslovjem. Prav prepletanje naravnih in družbenih dejavnikov, ki vplivajo na življenje ljudi na podeželju, je pri razvojnih prizadevanjih na teh območjih še bolj poudarjeno kot npr. pri regionalnem razvoju ali pri reševanju razvojnih problemov mest. Podeželje v sodobnem času razumemo kot prostor, za katerega je bistvena sestavina ravno neposredna povezanost z naravo in naravnim okoljem. Zaradi poznavanja številnih in močno prepletenih povezav med naravnimi in družbenimi dejavniki, ki delujejo pri preoblikovanju zemeljskega površja, smo geografi lahko najmanj enakovredni partnerji v strokovnih skupinah, ki pripravljajo in izdelujejo razvojne programe in oblikujejo razvojne projekte za podeželska območja. Hkrati imamo tudi razvite ustrezne metode za analizo številnih problemov, ki se pojavljajo na podeželju pa tudi metode, s katerimi lahko pomagamo odkriti skrite razvojne vire in moč posameznih podeželskih območij.

Analitični del CRPOV poteka v okviru petih vsebinskih sklopov, ki so, morda ne najbolj posrečeno, poimenovani kot prostori (družbeni, gospodarski,

\footnotetext{
${ }^{2}$ Strength, Weakness, Opportunities, Threats!
} 
kulturni, naselitveni, življenjski). Tudi delitev na navedenih pet področij bi bila verjetno lahko drugačna, saj sama po sebi ustvarja precej nejasnosti glede tega, kaj sodi v posamezen »prostor«. Geografske teme so zajete predvsem v okviru življenjskega prostora (pri analizi območja: geografski položaj, geološke, pedološke, hidrološke, klimatske značilnosti, rastlinstvo in živalstvo; okolje - stanje in odnos do okolja; krajinske in prostorsko-ureditvene značilnosti; materialna infrastruktura - stanje in potrebe...), seveda pa tudi v vseh drugih najdemo vsebine, s katerimi se raziskovalno ukvarjamo tudi geografi (morfologija naselij, funkcije naselij, prebivalstvene strukture, raba zemljišč, zastopanost različnih dejavnosti itn.)

Katere so torej naloge, ki jih lahko v okviru projekta CRPOV opravijo geografi:

- priprava sistematičnega geografskega orisa območja, kjer poteka program uvajanja:

- analiza naravnih in družbenih značilnosti območja vključno z vzpostavitvijo ustreznega GIS

- izdelava kartografskih prikazov posameznih vsebin

- predstavitev glavnih geografskih značilnosti prebivalcem območja

- izvajanje terenskih raziskav:

- kartiranje

- anketiranje, intervjuji...

- $\quad$ sodelovanje pri izdelavah analiz razvojnih možnosti:

- možnosti za spremembe rabe zemljišč

- možnosti za uvajanje novih (dopolnilnih) dejavnosti

- možnosti širitve in urejanja naselij

- vzpostavitev ustrezne infrastrukturne opremljenosti in oskrbe

- itn.

V okviru programov CRPOV za majhna območja je lahko geografsko raziskovanje usmerjeno $\mathrm{v}$ podrobne preučitve posameznih problemov oziroma tematik, seveda s ciljem, prispevati potrebne podlage za ustrezno opredelitev razvojnih ciljev in oblikovanje nalog za njihovo doseganje. V mislih imamo raziskave, ki so jih geografi opravljali že do sedaj, vendar pogosteje v čisto raziskovalne namene kot za praktično uporabo. V okviru raziskovanja preobrazbe podeželja so to raziskave, ki se nanašajo na družbenoekonomske spremembe, ki jih je doživelo podeželje in na njihove posledice. Poznavanje splošnih zakonitosti tovrstnih sprememb in praktičnih primerov tako iz Slovenije kot iz sveta je lahko zelo dobra podlaga za usmerjanje razvoja na obravnavanih območjih. V okvir raziskovanja gospodarskih značilnosti podeželja sodijo preučitve naravnih in družbenih dejavnikov za kmetijsko dejavnost (primernost in ustreznost rabe posameznih zemljišč, velikost uspešnost ter usmerjenost kmetijske pridelave $\mathrm{v}$ povezavi $\mathrm{z}$ agrarnimi sistemi, posestna 
struktura in razdrobljenost, kmečka delovna sila, mehaniziranost kmetij ipd.). Poleg kmetijstva in gozdarstva so na podeželju vse bolj prisotne in pomembne tudi nekmetijske dejavnosti, bodisi kot dopolnilo temeljni kmetijski dejavnosti, bodisi kot samostojne dejavnosti za pridobivanje sredstev za življenje podeželskega prebivalstva. Raziskovalno so na področje preučevanja teh dejavnosti in njihove vloge za gospodarski položaj podeželskega prebivalstva in podeželskih skupnosti geografi že posegli predvsem s preučevanjem turizma na kmetijah pa tudi drugih dopolnilnih dejavnosti. Problematika infrastrukturne opremljenosti podeželskih naselij, dostopnosti in oskrbe so ravno tako del raziskovalnega področja geografije in hkrati temeljni gradniki uspešnega razvoja slehernega podeželskega območja. Tudi raziskovanje vplivov na okolje in vrednotenje ukrepov za trajnostno rabo naravnih virov na podeželju je ena od aktualnih tem, ki se jim posvečamo geografi. Raziskovalna spoznan-ja s tega področja so tudi pomembna za uspešno načrtovanje izboljšanja življenja ljudi na podeželju. Tudi prebivalstvene raziskave geografom niso tuje. Vpliv starostne, izobrazbene, poklicne in drugih struktur prebivalstva na razvojne možnosti podeželskih območij ni zanemarljiv. Konec koncev ne smemo pozabiti tudi na morfološke značilnosti naselij, tipološko razvrščanje naselij in kmečkih domov, preučevanje takih posebnosti kot so kozolci ipd. Pri vseh teh stvareh smo geografi bili in smo raziskovalno prisotni s svojim pristopom in svojim pogledom na problematiko. Naši raziskovalni rezultati so lahko ključnega pomena $\mathrm{v}$ okviru interdisciplinarnega pristopa $\mathrm{k}$ preučevanju prostorskih in ureditvenih problemov podeželskih območij in tehten prispevek $\mathrm{k}$ iskanju ustreznih rešitev.

Geografi pa lahko v svoje raziskovalno polje uvrstimo tudi preučevanje razvoja podeželja. Na podlagi dosedanjih izkušenj je treba ugotoviti kako so projekti CRPOV in druge oblike razvojnih ukrepov spreminjali stanje na slovenskem podeželju, katere oblike delovanja so bile uspešnejše, kakšne raziskovalne podpore so potrebni projekti razvoja podeželja, da prinašajo čim boljše rezultate. Za uporabno geografijo podeželja je torej dovolj možnosti in priložnosti.

\section{SKLEP}

Geografija podeželja ima v Sloveniji dokaj dolgo tradicijo in je v okviru sistema geografske vede bolj trdno zasidrana kot marsikje drugje v svetu. Geografi so do neke mere tudi v praksi uporabljali svoje znanje s tega področja. Posamezni avtorji s svojimi objavami nakazujejo težnjo tudi $\mathrm{k}$ uporabnosti raziskovalnih rezultatov. V sedanjem času je nedvomno priložnost za uporabno raziskovanje program celostnega razvoja podeželja s številnimi projekti, ki 
potekajo na manjših zaokroženih območjih (t. i. projekti CRPOV). V strokovne skupine, ki vodijo tovrstne projekte, so se že vključevali posamezni geografi in tudi ustanove (npr. GIAM). Dosedanji prispevek geografov pa je bil bistveno manjši, kot bi lahko bil. Področij, ki jih v metodološkem in vse-binskem smislu ustrezno obvladujemo geografi je, veliko in sami, predvsem pa v sodelovanju s strokovnjaki drugih področij (agronomi, arhitekti, ekono-misti, gozdarji, krajinarji, sociologi ...), bi lahko zagotovili ustrezno podporno okolje za uspešen razvoj posameznih podeželskih območij kot tudi celotnega slovenskega podeželja.

$\mathrm{Za}$ vodenje programov uvajanja CRPOV in izdelovanja razvojnih projektov, potrebujejo diplomirani geografi le nekaj dodatnega znanja in izkušenj. $\mathrm{V}$ okviru podiplomskega izobraževanja bi jim bilo treba zagotoviti dodatno znanje iz ekonomije, vodenja in upravljanja (iz projektnega vodenja, uporabe različnih metod za analize razvojnih možnosti, porajanje idej ipd. npr. obvladovanje metode medsebojnega sodelovanja, SWOT analize, pisanja scenarijev, »brain storming-a« ...).

\section{Literatura:}

Hagget, P., 1983. Geography. A modern synthesis. New York, Harper Collins Publishers Inc., 644.

Kladnik, D., 1999. Leksikon geografije podeželja. Ljubljana, Inštitut za geografijo, 318.

Pelc, S. (ur.), 1999. Navodila za izvedbo programa uvajanja CRPOV in izdelavo razvojnega projekta CRPOV. Ljubljana, RS MKGP Sektor za razvoj podeželja, 112.

Pelc, S., 2002. Rural development and marginal areas in Slovenia. V: Jussila, H., Majoral, R., Cullen, B.: Sustainable Development and Geographical Space. Aldershot: Ashgate, 99-112.

Waugh, D., 1995. Geography: An Integrated Approach. Melbourne, Thomas Nelson and Sons Ltd., 593.

\section{GEOGRAPHY AND SUSTAINABLE DEVELOPMENT OF THE COUNTRYSIDE}

\section{Summary}

Slovenia is a predominantly rural country with only two major cities exceeding the population of 100,000 and with relatively low level of urbanisation. 
Slovene geographers are more engaged with the research of rural areas since the emergence of intensive transformation of these areas in the sixties. They were studying the problems of social and demographic structure, the migration flows between urban and rural areas, the problem of (sub)urbanisation and depopulation as well as problems related with agriculture and natural and social conditions for it. Regional planning in rural areas was also an important field of geographical research. Relatively important role of rural geography within the scheme of Slovene geography is evident as it is a regular course in study programmes of both Slovene universities. This is not the case in many foreign universities. However, the comparison among urban and rural geographic studies on the basis of bibliographical units in the library of the department of geography (University of Ljubljana) shows that rural areas attracted less attention than urban. And among the published books and arti-cles of Slovene authors there are not many that could be classified as at least to some extent applicative.

In the last decade the opportunity to apply the research results of rural geography is the national project of integrated rural development and the village renovation. This project started in 1991 (Pelc 2002). It followed the Bavarian example and was and still is lead by the Ministry of Agriculture, Forestry and Nutrition. It is based on the bottom-up approach and consists out of several small local projects (programmes), which are financed partly by the Ministry and partly by the municipalities. The role of the Ministry is one of co-ordination while the executive role is handed over to a competent (planning) institute chosen by the municipality on the basis of a public tender. The local projects are supposed to have three stages: the preparatory, the introductory (approximately one year) and the implementation stage (a long term task). The initiative group within the locality (a village or a local community) performs the preparatory stage with the intention to opt for public funding for its development. The final result of this stage is widely spread information about the project, readiness of the local population to become involved in the project and the application for a public tender. In this stage geographical analysis and description of basic characteristics of the locality is an important task that can be done by rural geographers.

In the introduction stage a competent institute forms an interdisciplinary expert team that has to achieve the following main tasks:

- to educate and train the local population for developmental thinking and acting;

- to formulate the developmental philosophy of the locality;

- to find local developmental motivation ("spiritus movens" of the locality); 
- to elaborate the synthetic developmental plan of the locality on the basis of SWOT analysis including objectives, tasks and the list of developmental projects that are to be implemented in the following stage;

- to encourage active participation of the local population;

- to form a local developmental initiative group capable of launching developmental projects.

The implementation stage is based on the public funding of selected common and individual developmental projects. The localities and individual investors apply for funding on the basis of a public tender of different Ministries for projects in different fields (infrastructure, small business, agriculture, culture, social affairs etc.).

The working field of applied rural geography within this kind of projects is partly analysis of the present developmental situation of the area under investigation, its developmental potentials and to form a research basis for the formation of developmental philosophy and for the defining of the appropriate objectives and tasks. Analytical part of each local project of integrated rural evelopment consists out of five fields: living conditions, settlement characteristics, economic, social and cultural area. The research within the first field includes systematic geographical analysis of the area and its presentation to the local population within the workshop where the SWOT analysis of the living conditions of the locality is made. Within the second one Slovene geographers have long research tradition from typology of rural settlements to their morphological characteristics. The application of geographical research in this field together with the findings and applied knowledge of architects and landscape designers is of crucial importance for the definition of the desired future changes within the physiognomy and the structure of the settlements. This also includes the investigation of infrastructure networks (power, water supply, sewage, roads). The rest of the fields are also at least to some extent covered by the geographical research field (natural and social potentials for agriculture, tourism on the farm etc. as well as demographic studies...) With some additional knowledge from project management and some experiences with group facilitation, geographers could also be good moderators of workshops and leaders of expert teams working on the projects of integral rural development. The important role of applied rural geography is of course studying and evaluating different processes that take place within rural development and to suggest the improvements of the concepts that are currently in use in rural development support in Slovenia. 